\title{
THE EFFECT OF SEQUESTRENE AND HEPARIN ON THE ERYTHROCYTE SEDIMENTATION RATE
}

\author{
BY \\ K. W. DENSON \\ From the Department of Clinical Pathology, University College Hospital (St. Pancras Hospital), London
}

(RECEIVED FOR PUBLICATION OCTOBER 10, 1958)

The Westergren method for the determination of the erythrocyte sedimentation rate has been conclusively shown to be more reliable than other methods (Gilmour and Sykes, 1951 ; Goldberg, Glynn, and Bywaters, 1952 ; Lewi and Clarke, 1954 ; Alexander and Andrews, 1957 ; Eastham, Denson, and Evans, 1958).

Blood for a variety of haematological and biochemical investigations is commonly collected into Wintrobe oxalate mixture, heparin, or sequestrene (ethylenediamine tetra-acetic acid), as anticoagulant. The use of such blood samples for determining the erythrocyte sedimentation rate obviates the necessity of collecting a separate specimen.

Rourke and Plass (1929) have shown by the addition of heparin to haemophilic blood that heparin itself has no effect on sedimentation when used at a concentration of 20 units $/ \mathrm{ml}$. but that an excessive amount increases the sedimentation rate. Both heparin and oxalate when used as anticoagulants in determining the E.S.R. have been shown to give anomalously low one-hour readings. These low readings have been abolished and greatly increased readings obtained by the addition of $3.8 \%$ sodium citrate as used in the standard Westergren method (Goldberg et al., 1952 ; Lewi and Clarke, 1954). In these cases the addition of sodium citrate produces three effects : (1) Lowering of the packed cell volume by simple dilution ; (2) further lowering of the P.C.V. due to cell shrinkage by the hypertonic sodium citrate ; (3) dilution of the plasma proteins.

Effects (1) and (2) increase the sedimentation rate since this is inversely proportional to the P.C.V. (Meyers, Trevorrow, Washburn, and Mugrage, 1953 ; Lawrence, 1953) and outweigh the effect of (3) which decreases the sedimentation rate (Fåhraeus, 1929 ; Lewi and Clarke, 1954).

The effect of sequestrene on erythrocyte sedimentation has not been investigated. Ham and Curtis (1938) and Mårtensson and Hansen (1953) have demonstrated that the addition of oxalate mixture to citrated blood has no effect on the
E.S.R. The present investigation was undertaken to evaluate the effect of sequestrene on erythrocyte sedimentation, and to compare the effect of the addition of $3.8 \%$ sodium citrate to blood which had been collected into heparin or sequestrene with citrated blood as used in the standard Westergren method.

\section{Methods}

Twenty millilitres of blood was obtained by venepuncture using a wide bore needle, and quickly distributed into calibrated tubes in the following manner:

(1) $8 \mathrm{ml}$. into $16 \mathrm{mg}$. of sequestrene (dry sodium salt) to give a final concentration of $2 \mathrm{mg} . / \mathrm{ml}$.

(2) $8 \mathrm{ml}$. into 160 units of dry heparin to give a final concentration of 20 units $/ \mathrm{ml}$.

(3) $4 \mathrm{ml}$. into $1 \mathrm{ml}$. of $3.8 \%$ trisodium citrate.

One millilitre of $3.8 \%$ sodium citrate was then added to $4 \mathrm{ml}$. of the heparinized and sequestrenized blood and the samples containing sequestrene, sequestrene + citrate, heparin + citrate, and citrate allowed to stand at room temperature for half an hour. After this time they were thoroughly mixed, and, using standard Westergren sedimentation pipettes of $2.5 \mathrm{~mm}$. bore, $200 \mathrm{~mm}$. columns of blood from each sample were set up in triplicate in sedimentation racks at room temperature. The separate samples were quickly mixed between each set of triplicate tubes and the time of insertion of each tube noted in order to ensure that readings were made at exactly 60 minutes.

The heights of the supernatant plasma columns of were measured at three-minute intervals for a period $N$ of 60 minutes, and from the readings graphs of time N against plasma height were plotted, and the maximum $\omega$ sedimentation rates obtained (240). The same set of tubes and stands were used throughout the series.

Blood samples were obtained from patients in whom a raised sedimentation rate was anticipated. Because $\stackrel{\odot}{+}$ of this method of selection and the inclusion of $\square$ extreme cases, together with the small sample size, a ${ }_{0}$ few values were rejected as outliers for the purpose $\mathbb{D}$ of the calculations, since it was felt that a simple analysis would be misleading.

For rejections in Tables I and II Cochran's test was applied $(\mathrm{P}<1 \%)$. 
For rejections in Table III the test statistic $q=\frac{w}{s}$ $(\mathrm{P}<1 \%)$ was applied.

\section{Results}

Tables I and II give the 20 estimates of the variance ( 2 degrees of freedom mean squares) of the 60 minute readings and maximum sedimen-

TABLE I

MEAN SOUARES OF DIFFERENCES FOR TRIPLICATE ES.R. DETERMINATIONS FOR EACH ANTICOAGULANT SERIES

\begin{tabular}{|c|c|c|c|c|}
\hline \multicolumn{5}{|c|}{ One Hour Readings } \\
\hline & equestrene & Citrate & $\begin{array}{c}\text { Sequestrene } \\
+ \\
\text { Citrate }\end{array}$ & $\begin{array}{c}\text { Heparin } \\
+ \\
\text { Citrate }\end{array}$ \\
\hline & $\begin{array}{r}0 \cdot 00 \\
0 \cdot 22 \\
0.89 \\
1 \cdot 56 \\
1 \cdot 56 \\
1 \cdot 56 \\
2 \cdot 00 \\
4 \cdot 67 \\
8 \cdot 00 \\
8 \cdot 22 \\
21 \cdot 56 \\
24 \cdot 00 \\
29 \cdot 56 \\
33 \cdot 89 \\
38 \cdot 89 \\
53 \cdot 54 \\
83.67 \\
128 \cdot 00 \\
141 \cdot 55 \\
1,689.92 \mathrm{R}\end{array}$ & $\begin{array}{l}0.00 \\
0.00 \\
0.00 \\
0.00 \\
0.22 \\
0.22 \\
0.22 \\
0.22 \\
0.22 \\
0.22 \\
0.22 \\
0.67 \\
0.67 \\
0.67 \\
0.67 \\
0.89 \\
0.89 \\
2.00 \\
2.67 \\
3.56\end{array}$ & $\begin{array}{c}0.00 \\
0.00 \\
0.00 \\
0.00 \\
0.00 \\
0.00 \\
0.00 \\
0.00 \\
0.22 \\
0.22 \\
0.22 \\
0.22 \\
0.67 \\
0.67 \\
0.67 \\
1.56 \\
2.00 \\
4.22 \mathrm{R} \\
5.56 \mathrm{R} \\
108.67 \mathrm{R}\end{array}$ & $\begin{array}{r}0.00 \\
0.00 \\
0.00 \\
0.00 \\
0.00 \\
0.00 \\
0.00 \\
0.22 \\
0.22 \\
0.67 \\
0.89 \\
0.89 \\
1.56 \\
1.56 \\
1.56 \\
2.00 \\
3.56 \\
4.67 \\
6.89 \\
10.89\end{array}$ \\
\hline $\begin{array}{l}\text { Average mean } \\
\text { square } \\
\text { S.D. } \\
\text { D.F. }\end{array}$ & $\begin{array}{l}30 \cdot 7 \\
5 \cdot 54 \\
38\end{array}$ & $\begin{array}{l}0 \cdot 71 \\
0 \cdot 84 \\
40\end{array}$ & $\begin{array}{l}0 \cdot 38 \\
0 \cdot 62 \\
34\end{array}$ & $\begin{array}{l}1 \cdot 78 \\
1 \cdot 33\end{array}$ \\
\hline $\begin{array}{l}\text { S.D. } 20 \text { cases } \\
\text { D.F. }\end{array}$ & $\begin{array}{l}10 \cdot 66 \\
40\end{array}$ & $\begin{array}{l}0 \cdot 84 \\
40\end{array}$ & $40^{2 \cdot 50}$ & $40^{1 \cdot 33}$ \\
\hline
\end{tabular}

N.B. Each mean square has 2 degrees of freedom. $R=$ Rejected by outlier test.

tation rates for the four anticoagulant series. These are given in their ranked orders of increasing size and clearly are not homogeneous. A few significantly large variance estimates have been rejected as outliers whenever they form more than a reasonable fraction of the total for the group (Cochran, 1941; Eisenhart and Solomon, 1947). These rejections do not lead to any substantial differences for the average variance estimates between the series as shown in Tables I and II. The standard deviations for citrate + heparin, citrate + sequestrene, and citrate agree well as a group and with previous estimates of the standard deviation for citrate + oxalate (Eastham et al., 1958). However, the standard deviation for sequestrene is significantly greater in comparison, and indicates a high degree of variability inherent in the use of sequestrene alone, as has been previously shown for potassium/ammonium oxalate mixture and heparin.
TABLE II

MEAN SOUARES OF DIFFERENCES FOR TRIPLICATE E.S.R. DETERMINATIONS FOR EACH ANTICOAGULANT SERIES

\begin{tabular}{|c|c|c|c|c|}
\hline \multicolumn{5}{|c|}{ Maximum Sedimentation Rates } \\
\hline Seq & uestrene & Citrate & $\begin{array}{c}\text { Sequestrene } \\
+ \\
\text { Citrate }\end{array}$ & $\begin{array}{c}\text { Heparin } \\
+ \\
\text { Citrate }\end{array}$ \\
\hline & $\begin{array}{l}0.00 \\
0.00 \\
0.00 \\
0.002 \\
0.007 \\
0.016 \\
0.024 \\
0.027 \\
0.029 \\
0.029 \\
0.029 \\
0.036 \\
0.043 \\
0.058 \\
0.122 \\
0.142 \\
0.149 \\
0.363 \\
0.746 \\
0.802\end{array}$ & $\begin{array}{l}0.00 \\
0.00 \\
0.00 \\
0.00 \\
0.00 \\
0.00 \\
0.002 \\
0.002 \\
0.002 \\
0.002 \\
0.002 \\
0.002 \\
0.002 \\
0.002 \\
0.002 \\
0.003 \\
0.009 \\
0.016 \\
0.016 \\
0.016\end{array}$ & $\begin{array}{l}0.00 \\
0.00 \\
0.00 \\
0.00 \\
0.00 \\
0.00 \\
0.00 \\
0.00 \\
0.002 \\
0.002 \\
0.002 \\
0.002 \\
0.002 \\
0.002 \\
0.003 \\
0.003 \\
0.003 \\
0.009 \\
0.020 \mathrm{R} \\
0.629 \mathrm{R}\end{array}$ & $\begin{array}{l}0.00 \\
0.00 \\
0.00 \\
0.00 \\
0.00 \\
0.00 \\
0.002 \\
0.002 \\
0.002 \\
0.002 \\
0.002 \\
0.002 \\
0.002 \\
0.003 \\
0.007 \\
0.007 \\
0.009 \\
0.021 \\
0.096 \mathrm{R} \\
0.229 \mathrm{R}\end{array}$ \\
\hline $\begin{array}{l}\text { Average mean } \\
\text { square } \\
\text { S.D. } \\
\text { D.F. }\end{array}$ & $\begin{array}{l}0 \cdot 131 \\
0 \cdot 362 \\
40\end{array}$ & $\begin{array}{l}0.0039 \\
0.063 \\
40\end{array}$ & $\begin{array}{l}0.0017 \\
0.041 \\
36\end{array}$ & $\begin{array}{l}0.0034 \\
0.058 \\
36\end{array}$ \\
\hline
\end{tabular}

N.B. Each mean square has 2 degrees of freedom. $R=$ Rejected by outlier test.

TABLE III

COMPARISON OF ARITHMETIC MEANS OF TRIPLICATE E.S.R.S IN THREE ANTICOAGULANT MIXTURES WITH THOSE USING CITRATE ALONE

\begin{tabular}{|c|c|c|c|}
\hline \multicolumn{4}{|c|}{ One Hour Readings Showing Difference from Citrate (mm.) } \\
\hline & iequestrene & $\begin{array}{c}\text { Sequestrene } \\
+ \text { +Citrate }\end{array}$ & $\begin{array}{l}\text { Heparin } \\
+ \text { Citrate }\end{array}$ \\
\hline & $\begin{array}{c}-80.33 \mathrm{R} \\
-41.67 \mathrm{R} \\
-23.00 \mathrm{R} \\
-9.33 \\
-0.33 \\
1.00 \\
1.33 \\
1.67 \\
2.33 \\
7.00 \\
10.33 \\
10.67 \\
11.00 \\
11.33 \\
14.00 \\
16.00 \\
17.16 \\
19.67 \\
21.33 \\
26.33 \mathrm{R}\end{array}$ & $\begin{array}{c}-20.67 \mathrm{R} \\
-2.00 \\
-2.00 \\
-1.67 \\
-0.67 \\
0.00 \\
0.00 \\
0.33 \\
1.33 \\
2.33 \\
2.67 \\
2.67 \\
3.67 \\
4.00 \\
4.33 \\
6.00 \\
6.00 \\
6.33 \\
9.33 \\
19.33 \mathrm{R}\end{array}$ & $\begin{array}{r}-0.33 \\
-0.33 \\
1.00 \\
1.00 \\
1.33 \\
1.67 \\
2.00 \\
2.67 \\
2.67 \\
3.33 \\
4.00 \\
4.33 \\
4.33 \\
6.00 \\
6.67 \\
6.67 \\
8.00 \\
10.00 \\
10.00 \\
16.33\end{array}$ \\
\hline \multirow{2}{*}{$\begin{array}{l}\text { Arithmetic } \\
\text { mean } \\
\text { S.D. } \\
\text { *Coefficient of } \\
\text { variance } \\
\text { S.D. (20 cases) }\end{array}$} & $\begin{array}{r}+8.45 \\
8.22\end{array}$ & $\begin{array}{r}+2 \cdot 37 \\
3 \cdot 15\end{array}$ & $\begin{array}{r}+4.53 \\
4.58\end{array}$ \\
\hline & $\begin{array}{l}13 \cdot 0 \\
24 \cdot 71\end{array}$ & $\begin{array}{l}5 \cdot 0 \\
7 \cdot 24\end{array}$ & $\begin{array}{l}7 \cdot 3 \\
4 \cdot 58\end{array}$ \\
\hline
\end{tabular}

N.B. * This is not Pearson's coefficient of variation, but is obtained by expressing as a percentage the S.D. divided by the average of the $\mathbf{2 0}$ arithmetic means for the citrate readings.

$\mathbf{R}=$ Rejected by outlier test.

In Table III the differences between the arithmetic means of the triplicate citrated samples and the triplicate samples of the remaining anticoagulant series are evaluated with reference 
to citrate as standard. A few values in each group have again been rejected as outliers. The standard deviations for citrate + heparin and citrate + sequestrene are again small, whilst the standard deviation for sequestrene is much greater. The order of probability for differences from citrate for each of the three other anticoagulant series is shown in Table IV. However, estimates of frequency are only tentative.

TABLE IV

PROBABILITY FOR DIFFERENCES FROM CITRATE

\begin{tabular}{|c|c|c|c|c|}
\hline \multicolumn{2}{|c|}{$\begin{array}{c}\text { Difference from Citrate } \\
\text { at } \\
\text { One-hour Readings (mm.) }\end{array}$} & $\begin{array}{c}\text { Sequestrene } \\
(\%)\end{array}$ & $\begin{array}{l}\text { Sequestrene } \\
+ \\
\text { Citrate }(\%)\end{array}$ & $\begin{array}{c}\text { Heparin } \\
+ \\
\text { Citrate (\%) }\end{array}$ \\
\hline $\begin{array}{ccc}\text { Greater than } & 10 \\
, ", & , & 15 \\
,, & , & 20 \\
,, & , & 25 \\
, & 30\end{array}$ & $\begin{array}{l}\cdots \\
\cdots \\
\cdots \\
\cdots\end{array}$ & $\begin{array}{r}43 \cdot 7 \\
21 \cdot 4 \\
7 \cdot 2 \\
2 \cdot 3 \\
0 \cdot 4\end{array}$ & $\begin{array}{l}0 \cdot 8 \\
0 \cdot 0 \\
0 \cdot 0\end{array}$ & $\begin{array}{r}11.0 \\
1.0 \\
0.0\end{array}$ \\
\hline
\end{tabular}

Assuming a normal distribution of differences between citrate (mean of three) and each of the other series, this table indicates the order of probability for differences (plus or minus) from citrate, taking into account the mean differences derived from the 20 cases.

\section{Discussion}

Dilution of heparinized and sequestrenized samples with citrate instead of physiological saline was chosen in order to obtain a quantitative comparison with the Westergren method, in which the same conditions of dilution and cell shrinkage apply. The added effects of heparin and sequestrene at their normal concentrations would, it was anticipated, have little effect in this respect.

It has been shown by Lewi and Clarke (1954) that dilution, far from being undesirable, tends to give a more accurate correlation of the sedimentation rate with clinical condition. In cases where the "rouleaux formation intensity" (R.F.I.), or sedimenting power, and packed cell volume are high, and similarly in cases where the R.F.I. is high and the P.C.V. is low, dilution increases the sedimentation rate. In cases where the R.F.I. and P.C.V. are normal (the normal range) the sedimentation rate is decreased. Tube bore also becomes important at increased plasma viscosity and increased P.C.V. (Shannon and Bywaters, 1957); however, the overriding factor is that of dilution. Using the Westergren method, one case was seen recently of primary atypical pneumonia with a P.C.V. of $56 \mathrm{ml} . / 100 \mathrm{ml}$. and an E.S.R. of $5 \mathrm{~mm}$. at one hour. On correction of the P.C.V. to $46 \mathrm{ml}$./ $100 \mathrm{ml}$. the E.S.R. was $80 \mathrm{~mm}$. at one hour. It is evident that in this case the dilution employed in the standard method was still insufficient to bring the E.S.R. into the pathological range.
The results obtained in the present study show that dilution of heparinized or sequestrenized blood with $3.8 \%$ sodium citrate solution reduces the standard deviation between replicate readings to within the limits obtained for the standard Westergren method employing citrate alone. A similar finding has been demonstrated for dilution of oxalated blood with sodium citrate (Eastham et al., 1958). Also, if the arithmetic mean of the 60 minute citrate reading is accepted as being the standard sedimentation rate for each blood sample, the average arithmetic means of the 20 readings for the sequestrene + citrate and heparin + citrate series differ by only $+2 \mathrm{~mm}$. and $+4.5 \mathrm{~mm}$. respectively from the average arithmetic mean of the 20 citrate readings. Since each sample has been separately diluted with sodium citrate for each of these anticoagulant mixtures, the scatter about the mean is consistent with sampling, diluting, and mixing errors.

It is therefore suggested that the Westergren sedimentation rate may be determined using blood which has been collected into Wintrobe oxalate mixture, heparin or sequestrene, simply by diluting four volumes of blood with one volume of $3.8 \%$ sodium citrate.

\section{Summary}

(1) The anticoagulant sequestrene is unreliable for determining the erythrocyte sedimentation rate. This has previously been demonstrated in the case of heparin and potassium/ammonium oxalate mixture.

(2) Blood which has been collected into oxalate, heparin, or sequestrene, when subsequently diluted with one-fourth of its volume of $3.8 \%$ sodium citrate, is suitable for determining the Westergren sedimentation rate.

I wish to thank Professor M. Maizels for his advice and criticism, and Mr. R. Weightman and Miss Anne Bassett for advice with the statistics and for the many calculations.

\section{REFERENCES}

Alexander, W. D., and Andrews, M. M. (1957). Lancet, 1, 240.

Cochran, W. G. (1941). Ann. Eugen. (Lond.), 11, 47.

Eastham, R. D., Denson, K. W. E., and Evans, D. A. (1958). Acta med. scand., 161, 277.

Eisenhart, C., and Solomon, H. (1947). In Selected Techniques of Statistical Analysis, p. 383, by the Statistical Research Group, Columbia University, ed. C. Eisenhart, M. W. Hastay, and W. A. Wallis. McGraw-Hill, New York.

Fåhraeus, R. (1929). Physiol. Rev., 9, 241.

Gilmour, D., and Sykes, A. J. (1951). Brit. med. J., 2, 1496.

Goldberg, S., Glynn, L. E., and Bywaters, E. G. L. (1952). Ibid., 1,202 .

Ham, T. H., and Curtis, F. C. (1938). Medicine (Baltimore), 17, 447. Lawrence, J. S. (1953). Ann. rheum. Dis., 12, 206.

Lewi, S., and Clarke, K. T. (1954). Brit. med. J., 2, 336.

Martensson, E. H., and Hansen, H. A. (1953). Acta med. scand. $146,164$.

Meyers, A. J., Trevorrow, V., Washburn, A. H., and Mugrage, E. R. (1953). Blood, 8, 893.

Rourke, M. D., and Plass, E. D. (1929). J. clin. Invest., 7, 365. Shannon, F. T., and Bywaters, E. G. L. (1957). Brit. med. J., 2, 1405 